\title{
Estéticas da existência: subjetivações sobre a moda
}

\section{Lorena Pompei \\ ABDALA}

\section{Resumo}

Como se dariam as propensões e noções de gosto? Pensando nas práticas de si é que se buscará, neste estudo, a transcendência do utilitarismo da moda para uma noção de subjetivação e experiência estética. Entendimento do posicionamento identitário legitimado pelas múltiplas dobras e territórios ocupados pelos sujeitos. Em maior ou menor grau possuímos objetivações e subjetivações de gosto relacionadas às práticas da aparência ou existência. Todos nós vemos e somos vistos, portanto de uma forma ou de outra é pouco provável um absoluto alheamento de si mesmo e dos outros. Somos artefatos visuais e portamos informações imagéticas. Negar a estética de si, no sentido foucaultiano, seria negar a própria existência, já que a constituição do Eu esta ligado à imagem do próprio corpo, segundo o "Estádio do Espelho" de Jacques Lacan. Assim, pensemos em corpos construídos por um discurso, corpos que se projetam pelas experiências estéticas como um meio de comunicação subjetiva com o mundo, corpos percebidos pela poética da obra aberta, que admitem um universo de formas perceptíveis e interpretações plurais que se complementam e geram novas formas de perceptos. Palavras-chave: Moda; Estética; SubjetividadeO texto de Daniel Arasse (Arte e cincia: funes do desenho em Leonardo da Vinci) desfaz a tradicional separação entre os desenhos "científicos", sobretudo anatômicos, e os desenhos "artísticos" de Da Vinci. Seu estudo visa indicar que, para o artista renascentista, não havia contradição nessas duas práticas, embora os resultados produzidos pareçam antitéticos. Já Georges Didi-Huberman (Pensamento por imagem, pensamento dialtico, pensamento alterante: a infncia da arte segundo Georges Bataille) mostra-nos os conceitos tramados por Bataille no final dos anos 20, na revista Documents, a respeito da arte primitiva e infantil como modelos para pensar a criação da imagem. Para tanto, Didi-Huberman explora a tensão entre dialtica das formas ("sintomas do sentido"), criada pelo francês, e a noção dialética fundada por Hegel ("advento do sentido"), assim como também destaca a construção das imagens como regressão (Freud) e alteração (Luquet).

Palavras-chave: Moda, estética, subjetividade. 